\title{
PENGEMBANGAN PERANGKAT PEMBELAJARAN KOOPERATIF TIPE JIGSAW PADA MATERI KONSEP LARUTAN DI SMK NEGERI 3 BANTAENG
}

\author{
Samsinar Saleh $^{1}$, Muhammad Danial ${ }^{2}$, Yusminah Hala ${ }^{3}$ \\ ${ }^{1}$ Guru SMK Negeri 3 Bantaeng \\ ${ }^{2,3}$ Dosen Program Pascasarjana Universitas Negeri Makassar \\ Email: samsinar@yahoo.com
}

\begin{abstract}
ABSTRAK
Penelitian ini merupakan penelitian pengembangan (research and development) yang bertujuan untuk: (1) memperoleh gambaran proses pengembangan perangkat pembelajaran kooperatif tipe Jigsaw yang valid, praktis, dan efektif, (2) mengetahui tinhgkat kevalidan, kepraktisan, dan keefektifan perangkat pembelajaran kooperatif tipe Jigsaw pada materi Konsep Larutan di SMK Negeri 3 Bantaeng. Subjek penelitian adalah siswa kelas X Keperawatan B SMK Negeri 3 Bantaeng dengan jumlah siswa 18 orang pada semester genap tahun pelajaran 2015/2016. Model pengembangan perangkat pembelajaran yang digunakan adalah model 4-D dari Thiagarajan, Semmel \& Semmel. Hasil pengembangan perangkat pembelajaran berupa draft RPP, Buku Peserta Didik (BPD) dan Lembar Kerja Peserta Didik (LKPD) yang dapat digunakan oleh guru dan siswa dalam proses pembelajaran materi Konsep Larutan. Tingkat keberhasilan dalam uji coba lapangan ditunjukkan oleh tes hasil belajar yang mencapai ketuntasan sebesar $100 \%$, respon positif dari siswa mencapai 93,70\% untuk buku peserta didik, 92,38\% untuk LKPD dan $85,24 \%$ untuk perangkat pembelajaran dan proses pembelajaran serta keterlaksanaan perangkat pembelajaran berada pada kriteria sangat tinggi. berdasarkan kriteria yang digunakan untuk menilai perangkat pembelajaran yang dihasilkan yaitu kevalidan, keefektifan dan kepraktisan, maka perangkat pembelajaran yang dikembangkan memenuhi kualitas baik.
\end{abstract}

Kata kunci: Perangkat Pembelajaran, Kooperatif Tipe Jigsaw, dan Konsep Larutan.

\begin{abstract}
This research is the development (research and development) which aims to: (1) obtain a picture of the development process of the type cooperative learning of Jigsaw valid, practical, and effective, (2) determine tinhgkat validity, practicality, and effectiveness of the cooperative learning of Jigsaw the material solution concept at SMK Negeri 3 Bantaeng. The subjects were students of class X SMK Nursing B 3 Bantaeng by the number of students 18 people in the second semester of the 2015/2016 academic year. Model development of learning tools used are 4-D models of Thiagarajan, Semmel \& Semmel. The result of the development of learning tools in the form of draft RPP, Books Students (BPD) and Worksheet Students (LKPD) that can be used by teachers and students in the learning process material solution concept. The level of success in field trials demonstrated by tests of learning outcomes that achieve mastery of $100 \%$, a positive response from the students reached 93.70\% for books learners, $92.38 \%$ and $85.24 \%$ for LKPD for the learning and the learning process and keterlaksanaan learning tools are at very high criteria. based on the criteria used to assess the resulting learning device that validity, effectiveness and practicality, the learning tools developed meet the quality is good.
\end{abstract}

Keywords: Learning Tool, Cooperative Jigsaw mode, and Concept solution. 


\section{PENDAHULUAN}

Ilmu Kimia mempunyai tingkat kesulitan yang tinggi berkaitan dengan konsep-konsep dalam Kimia bersifat abstrak, merupakan penyederhanaan dari keadaan sebenarnya, dan sifatnya berurutan. Kesulitan dalam memahami konsep-konsep dapat menyebabkan terjadinya kesalahan pemahaman. Pemahaman salah yang terjadi secara konsisten disebut dengan kesalahan konsep (misconception).

Guru harus paham benar akan perubahan budaya dan kebiasaan anak saat ini sehingga mampu mengembangkan pembelajaran yang tidak mematikan sikap kritis dan kreatifitas mereka, bahkan mendorong mereka untuk mengembangkan talenta yang mereka miliki. Proses pembelajaran harus melibatkan siswa sebagai subyek pembelajaran bukan sebagai obyek yang pasif menerima pelajaran.

Hal yang paling mendasar yang harus diingat bahwasanya teknologi tidak akan menjadi alat bantu yang baik dan kuat apabila pola pembelajarannya masih tradisional. Guru yang baik akan membuat keajaiban bukan teknologinya. Beberapa model pembelajaran dapat diterapkan oleh guru seperti model pembelajaran silang (Jigsaw) untuk memperkaya pengalaman belajar siswa (Learning Experience). Satu hal yang perlu dipahami bahwa siswa harus mengerti dan memahami hubungan antara ilmu yang dipelajari di sekolah dengan kehidupan nyata, siswa harus mampu menerapkan ilmunya untuk mencapai solusi permasalahan dalam kehidupan nyata.

Berdasarkan pengamatan yang dilakukan di sekolah, kebanyakan peserta didik menganggap bahwa pembelajaran Kimia sulit dan membosankan. Kurangnya pemahaman dan keaktifan siswa mengenai pembelajaran Kimia disebabkan karena guru masih menggunakan model pembelajaran konvensional. Model pembelajaran konvensional yang digunakan guru di sekolah ini adalah model pembelajaran langsung yaitu model yang bersifat teacher centered, dimana guru lebih aktif dalam kegiatan belajar mengajar dan kerjasama antar siswa masih kurang. Kurangnya pengetahuan guru mengenai model-model pembelajaran menyebabkan guru hanya menggunakan satu jenis model pembelajaran saja. Selain itu, metode pembelajaran yang digunakan juga kurang bervariasi, hanya menggunakan metode ceramah ataupun diskusi saja. Hal lain yang menyebabkan kurangnya aktivitas siswa dalam pembelajaran Kimia adalah sarana laboratorium yang kurang memadai sehingga jarang digunakan. Masalah tersebut di atas sangat mempengaruhi aktivitas dan minat belajar peserta didik.

Untuk menangani permasalahan di atas dapat diupayakan pemecahannya yaitu dengan mencoba tindakan-tindakan yang dapat mengubah suasana pembelajaran di dalam kelas. Suasana pembelajaran di dalam kelas hendaknya mengutamakan keaktifan peserta didik. Maka, salah satu solusi yang dapat dilakukan adalah menerapkan model pembelajaran kooperatif tipe Jigsaw . Untuk menerapkan model ini diperlukan ketersediaan perangkat pembelajaran. Oleh karena itu, sangat perlu untuk mengembangkan perangkat pembelajaran dengan pengembangan model pembelajaran Kooperatif Tipe Jigsaw. Model ini lebih menitikberatkan siswa untuk aktif bekerja sama. Perangkat pembelajaran Kimia yang sesuai sangat penting dalam upaya untuk mencapai tujuan pembelajaran. Selain itu perangkat pembelajaran dapat memberikan kemudahan peserta didik untuk belajar. Perangkat pembelajaran merupakan prasyarat bagi terjadinya interaksi belajar mengajar yang optimal. Jadi jelas bahwa dengan adanya perangkat pembelajaran akan mempengaruhi keberhasilan proses pemnbelajaran di kelas. Guru akan lebih mudah untuk mengajarkan suatu materi, sedangkan peserta didik akan lebih mudah untuk memahami materi yang diajarkan oleh guru. Oleh sebab itu perangkat pembelajaran mutlak diperlukan oleh seorang guru dalam mengelola pembelajaran.

Penelitian ini akan dikembangkan perangkat pembelajaran model kooperatif tipe Jigsaw pada materi Konsep Larutan. 
Pemilihan materi konsep larutan didasarkan bahwa materi ini cocok untuk penerapan model pembelajaran tipe Jigsaw karena mempunyai bahasan yang cukup luas. Dengan adanya model pembelajaran tipe Jigsaw ini diharapakan agar materi dapat tersampaikan secara efektif tanpa banyak membuang waktu serta penyampaian materi dapat terselesaikan dengan tuntas, sehingga siswa lebih mengerti karena proses belajar yang melibatkan mereka secara aktif dengan adanya kelompok ahli.

Perangkat pembelajaran yang akan dikembangkan dalam penelitian ini adalah Rencana Pelaksanaan Pembelajaran (RPP), Lembar Kerja Peserta Didik (LKPD), Buku Peserta Didik (BPD), dan Tes Hasil Belajar (THB).

Berdasarkan latar belakang masalah yang telah diuraikan di atas, maka rumusan masalah dalam penelitian ini adalah: (1) Bagaimana mengembangkan perangkat pembelajaran kooperatif tipe Jigsaw pada materi Konsep Larutan, yang valid, praktis dan efektif? (2) Bagaimana kevalidan, kepraktisan, dan keefektifan perangkat pembelajaran model kooperatif tipe Jigsaw pada materi Konsep Larutan?

Berdasarkan rumusan masalah di atas, maka tujuan dari penelitian ini adalah: (1) Untuk memperoleh gambaran proses pengembangan perangkat pembelajaran kooperatif tipe Jigsaw yang valid, praktis dan efektif. (2) Untuk memperoleh perangkat pembelajaran kooperatif tipe Jigsaw yang valid, praktis, dan efektif.

\section{METODE PENELITIAN}

Jenis penelitian ini digolongkan ke dalam penelitian pengembangan (research and development) yang meliputi pengembangan perangkat pembelajaran tipe Jigsaw yang terdiri dari rencana pelaksanaan pembelajaran (RPP), lembar kerja peserta didik (LKPD), buku peserta didik (BPD), dan tes hasil belajar (THB).

Untuk uji coba perangkat hasil pengembangan ini dilaksanakan di SMK Negeri 3 Bantaeng dan subjek penelitiannya adalah siswa kelas $\mathrm{X}$ dipilih kelas $\mathrm{X}$
Keperawatan B dari 10 kelas X paralel yang ada dengan jumlah siswa 18 orang pada semester genap tahun pelajaran 2015/2016.

Model pengembangan perangkat pembelajaran yang digunakan dalam penelitian ini merujuk pada model pengembangan Thiagarajan, Semmel \& Semmel (1974) dalam Trianto (2010: 93) adalah model 4-D. Model ini terdiri dari empat tahap pengembangan, yaitu define, design, develop, dan disseminate atau diadaptasikan menjadi model 4-P, yaitu pendefenisian, perancangan, pengembangan, dan penyebaran.

Adapun instrument penelitian yang digunakan adalah (1) lembar validasi perangkat pembelajaran (2) lembar observasi keterlaksanaan perangkat pembelajaran, (3) lembar observasi aktivitas siswa, (4) angket respon siswa, (5) angket respon guru, (6) tes hasil belajar (THB).

Analisi data yang digunakan dalam pengembangan perangkat pembelajaran ini adalah teknik analisis statistik deskriptif. data yang dianalisis yaitu: (1) analisis data kevalidan perangkat pembelajaran, (2) analisis data kepraktisan perangkat pembelajaran, (3) analisis data keefektifan perangkat pembelajaran, (4) analisis data respon guru.

\section{HASIL PENELITIAN DAN PEMBAHASAN \\ 1. Hasil Penelitian \\ a. Deskripsi Hasil Tahap Pengembangan (Develop)}

\section{Analisis data kevalidan perangkat pembelajaran}

Adapun perangkat pembelajaran yang telah divalidasi dapat dideskripsikan sebagai berikut:

a) Rencana Pelaksanaan Pembelajaran

Aspek-aspek yang diperhatikan dalam memvalidasi RPP adalah: kesesuaian tujuan, materi yang disajikan, bahasa, sarana dan alat bantu pembelajaran, metode dan kegiatan pembelajaran, serta alokasi waktu yang digunakan.

Kegiatan penilaian perangkat pembelajaran oleh validator diawali dengan 
memberikan perangkat pembelajaran beserta lembar penilaian kepada 2 orang ahli (validator). Instrumen penilaian yang divalidasi oleh para ahli, format validasi yang digunakan, dan hasil penilaian ahli terhadap perangkat dapat dilihat pada Lampiran. Hasil validasi dari ahli dapat dirangkum pada Tabel 4.1 .

Tabel 4.1 Rangkuman Hasil Validasi RPP

\begin{tabular}{cccc}
\hline No & $\begin{array}{c}\text { Aspek } \\
\text { penilaian }\end{array}$ & $\bar{x}$ & Ket \\
\hline 1 & $\begin{array}{c}\text { Kesesuain } \\
\text { tujuan } \\
\text { Materi yang } \\
\text { disajikan } \\
\text { Bahasa }\end{array}$ & 3,20 & Valid \\
3 & 3,25 & Valid \\
\hline 4 & $\begin{array}{c}\text { Sarana dan alat } \\
\text { bantu } \\
\text { pembelajaran }\end{array}$ & 3,50 & $\begin{array}{c}\text { Sangat } \\
\text { Valid }\end{array}$ \\
\hline 5 & $\begin{array}{c}\text { Metode dan } \\
\text { Kegiatan } \\
\text { pembelajaran }\end{array}$ & 3,33 & Valid \\
\hline 6 & $\begin{array}{c}\text { Alokasi Waktu } \\
\text { Rata-rata penilaian } \\
\text { total }\end{array}$ & 3,5 & $\begin{array}{c}\text { Sangat } \\
\text { Valid }\end{array}$ \\
\hline & $\begin{array}{c}\text { Percentage of } \\
\text { Agreement }\end{array}$ & 1,00 & Valid \\
\hline
\end{tabular}

Berdasarkan Tabel 4.1 menunjukkan bahwa nilai rata-rata kevalidan berada pada kategori valid, yaitu berada pada $(2,5 \leq \bar{x}$ $<3,5)$ dan berdasarkan perhitungan didapatkan koefisien reliabilitas $100 \%$ atau 1. Hasil analisis selengkapnya dapat dilihat pada Lampiran 7 (Halaman 195197). Penilaian secara umum oleh para ahli untuk RPP adalah baik dan dapat digunakan dengan sedikit revisi.

b) Buku Peserta Didik

Dalam penyusunan buku peserta didik, beberapa aspek yang perlu diperhatikan dalam memvalidasi perangkat, yaitu: penjabaran konsep, konstruksi buku siswa, karakteristik subkonsep, dan manfaat buku siswa. Hasil validasi dari ahli dapat dirangkum pada pada Tabel 4.2
Tabel 4.2 Rangkuman Hasil Validasi Buku Peserta Didik

\begin{tabular}{cccc}
\hline No & Aspek penilaian & $\bar{x}$ & Ket \\
\hline 1 & Penjabaran Konsep & 3,58 & Sangat \\
2 & Konstruksi & 3,39 & valid \\
3 & Karakteristik & 3,50 & Valid \\
4 & Subkonsep & 3,50 & Sangat \\
& Manfaat Buku & & Valid \\
& Peserta Didik & & Sangat \\
& & & Valid \\
\hline & Rata-rata total & 3,70 & Sangat \\
& & & Valid \\
\hline Percentage of Agreement & 1,00 & Reliabel \\
\hline
\end{tabular}

Berdasarkan Tabel 4.2 menunjukkan bahwa nilai rata-rata kevalidan berada pada kategori sangat valid, yaitu berada pada $(3,5$ $\leq x<4,0)$ dan berdasarkan perhitungan didapatkan koefisien reliabilitas $100 \%$ atau 1. Hasil analisis selengkapnya dapat dilihat pada Lampiran 7 (Hal 191-192). Penilaian secara umum oleh para ahli untuk buku peserta didik adalah baik dan dapat digunakan dengan sedikit revisi.

c) Lembar Kerja Peserta Didik (LKPD)

Dalam menyusun Lembar Kerja Peserta Didik (LKPD), beberapa aspek yang perlu diperhatikan dalam memvalidasi perangkat yaitu: aktivitas, materi yang disajikan, bahasa, dan waktu LKPD. Hasil validasi dari ahli dapat dirangkum pada pada Tabel 4.3

Tabel 4.3 Rangkuman Hasil Validasi LKPD

\begin{tabular}{|c|c|c|c|}
\hline No & Aspek penilaian & $\bar{x}$ & Ket \\
\hline 1 & Aktivitas & 3,50 & $\begin{array}{l}\text { Sangat } \\
\text { Valid }\end{array}$ \\
\hline 2 & $\begin{array}{l}\text { Materi } \\
\text { disajikan }\end{array}$ & 3,43 & $\begin{array}{c}\text { Sangat } \\
\text { Valid }\end{array}$ \\
\hline 3 & Bahasa & 3,36 & $\begin{array}{l}\text { Valid } \\
\text { Sangat }\end{array}$ \\
\hline 4 & Waktu & 3,50 & Valid \\
\hline & Rata-rata total & 3,45 & Valid \\
\hline $\mathrm{Pe}$ & ntage of Agreen & 1 & Reliabe \\
\hline
\end{tabular}

Berdasarkan Tabel 4.3 menunjukkan bahwa nilai rata-rata kevalidan berada pada kategori valid yaitu berada pada $(2,5 \leq \bar{x}$ $<3,5)$ dan berdasarkan perhitungan didapatkan koefisien reliabilitas $100 \%$ atau 1. Hasil analisis selengkapnya dapat 
dilihat pada Lampiran 7 (Hal 193-194). Penilaian secara umum oleh para ahli untuk LKPD adalah baik dan dapat digunakan dengan sedikit revisi.

d) Tes Hasil Belajar (THB)

Dalam menyusun tes hasil belajar (THB), beberapa aspek yang perlu diperhatikan dalam memvalidasi perangkat yaitu: karakteristik soal, konstruksi, dan bahasa. Hasil validasi dari ahli dapat dirangkum pada pada Tabel 4.4

Tabel 4.4 Rangkuman Hasil Validasi THB

\begin{tabular}{clcc}
\hline No & Aspek penilaian & $\bar{x}$ & Ket \\
\hline 1 & Karakteristik & 3,80 & SangatValid \\
2 & Soal & 3,38 & Valid \\
3 & Konstruksi & 3,67 & $\begin{array}{c}\text { Sangat } \\
\text { Valid }\end{array}$ \\
& Bahasa & & $\begin{array}{c}\text { Sangat } \\
\text { Valid }\end{array}$ \\
\hline & Rata-rata total & 3,61 & Reliabel \\
& Percentage of & 1 & \\
\hline & Agreement & & \\
\hline
\end{tabular}

Berdasarkan Tabel 4.4 menunjukkan bahwa nilai rata-rata kevalidan berada pada kategori sangat valid yaitu berada pada (3,5 $\leq x<4,0)$ dan berdasarkan perhitungan didapatkan koefisien reliabilitas $100 \%$ atau 1. Hasil analisis selengkapnya dapat dilihat pada Lampiran 7 (Hal 198). Penilaian secara umum oleh para ahli untuk THB adalah baik dan dapat digunakan dengan sedikit revisi.

Secara umum semua penilaian validator terhadap perangkat pembelajaran yang dikembangkan memberikan kesimpulan yang sama yaitu perangkat pembelajaran ini baik dan dapat digunakan dengan sedikit revisi. Dalam melakukan revisi, peneliti mengacu pada hasil diskusi dengan mengikuti saran-saran serta petunjuk validator.

\section{Analisis data kepraktisan perangkat pembelajaran}

a) Hasil Analisis Keterlaksanaan Perangkat Pembelajaran Kooperatif Tipe Jigsaw

$$
\text { Data kepraktisan perangkat }
$$

pembelajaran kooperatif tipe Jigsaw diperoleh melalui lembar observasi keterlaksanaan perangkat pembelajaran. Hasil pengamatan keterlaksanaan perangkat pembelajaran tersebut kemudian dianalisis untuk melihat tingkat kepraktisan perangkat pembelajaran kooperatif tipe Jigsaw yang telah disusun.

Hasil uji coba untuk melihat keterlaksanaan perangkat dapat dilihat pada Lampiran. Rangkuman hasil uji coba tersebut disajikan dalam Tabel 4.5

Tabel 4.5 Hasil Pengamatan Keterlaksanaan Perangkat Pembelajaran

\begin{tabular}{clcc}
\hline $\begin{array}{c}\mathrm{N} \\
\mathrm{O}\end{array}$ & \multicolumn{1}{c}{ Aspek } & $\begin{array}{c}\text { Rata- } \\
\text { Rata }\end{array}$ & Keterangan \\
\hline 1 & Sintaks & 2,0 & $\begin{array}{c}\text { Terlaksana } \\
\text { Seluruhnya }\end{array}$ \\
\hline 2 & $\begin{array}{l}\text { Interaksi } \\
\text { Sosial }\end{array}$ & 1,83 & $\begin{array}{l}\text { Terlaksana } \\
\text { Seluruhnya }\end{array}$ \\
\hline 3 & Prinsip reaksi & 1,98 & $\begin{array}{l}\text { Terlaksana } \\
\text { Seluruhnya }\end{array}$ \\
\hline 4 & $\begin{array}{l}\text { Sistem } \\
\text { pendukung }\end{array}$ & 2,0 & $\begin{array}{l}\text { Terlaksana } \\
\text { Seluruhnya }\end{array}$ \\
\hline Rata-rata Total (x) & 1,95 & $\begin{array}{l}\text { Terlaksana } \\
\text { Seluruhnya }\end{array}$ \\
\hline
\end{tabular}

Dari analisis data kepraktisan tersebut menunjukkan bahwa pelaksanaan perangkat pembelajaran kooperatif tipe Jigsaw terlaksana seluruhnya, maka perangkat pembelajaran yang dikembangkan dinyatakan memiliki derajat kepraktisan yang baik.

\section{b) Hasil Analisis Respon Guru Terhadap Pembelajaran Kooperatif Tipe Jigsaw}

Tujuan utama analisis data respon guru terhadap proses pembelajaran adalah untuk melihat bagaimana respon guru terhadap proses pembelajaran kooperatif tipe Jigsaw. Hasil analisis tersebut ditunjukkan pada Tabel 4.6

Tabel 4.6 Hasil Respon Guru

\begin{tabular}{|c|c|c|c|}
\hline No & Aspek & $\begin{array}{c}\text { Rata- } \\
\text { rata } \\
\text { Persenta } \\
\text { se }\end{array}$ & $\begin{array}{c}\text { Ketera } \\
\text { ngan }\end{array}$ \\
\hline 1 & $\begin{array}{l}\text { Penilaian terhadap } \\
\text { perangkat }\end{array}$ & 75,00 & Positif \\
\hline
\end{tabular}




\begin{tabular}{|c|c|c|c|}
\hline & $\begin{array}{l}\text { pembelajaran dan } \\
\text { instrumen penilaian } \\
\text { hasil belajar }\end{array}$ & & \\
\hline 2 & $\begin{array}{l}\text { Dukungan perangkat } \\
\text { pembelajaran pada } \\
\text { pelaksanaan tugas } \\
\text { mengajar di kelas } \\
\end{array}$ & 72,92 & Positif \\
\hline 3 & $\begin{array}{l}\text { Pertanyaan/pernyataa } \\
\mathrm{n} \\
\text { pembelajaran }\end{array}$ & 95,24 & $\begin{array}{l}\text { Sangat } \\
\text { Positif }\end{array}$ \\
\hline
\end{tabular}

\section{Analisis data keefektifan perangkat pembelajaran}

Suatu perangkat dikatakan efektif, apabila memenuhi persyaratan berikut: (1) lebih dari $50 \%$ siswa memberikan respon positif terhadap penerapan pembelajaran kooperatif tipe Jigsaw yang meliputi: respon terhadap buku siswa dan lembar kerja siswa , (2) aktivitas siswa dan guru memenuhi kriteria toleransi waktu yang telah ditetapkan, (3) ketercapaian hasil belajar siswa yaitu $80 \%$ atau berada pada ketuntasan klasikal.

\section{a) Hasil pengamatan aktivitas peserta didik}

Untuk memperoleh data aktivitas siswa, digunakan lembar observasi. Pengamatan dilakukan oleh dua orang observer (pengamat). Pengamatan aktivitas siswa dilakukan dengan mengamati satu kelompok kerja yang merupakan kelompok asal, dengan pertimbangan bahwa kelompok tersebut mewakili semua kelompok. Hasil analisis selengkapnya dapat dilihat pada Lampiran 7 (Hal 205). Adapun persentase rata-rata peserta didik selama proses pembelajaran tiga kali pertemuan ditunjukan pada Tabel 4.7

Tabel 4.7 Hasil Pengamatan aktivitas peserta didik

\begin{tabular}{clcc}
\hline No & Aspek penilaian & $\begin{array}{c}\text { Rata-rata } \\
\text { Persentase }\end{array}$ & Kategori \\
\hline 1 & $\begin{array}{l}\text { Memperhatikan } \\
\text { penjelasan guru }\end{array}$ & 100 & $\begin{array}{c}\text { Sangat } \\
\text { Baik }\end{array}$ \\
\hline 2 & $\begin{array}{l}\text { Bekerja sama } \\
\text { dalam kelompok }\end{array}$ & 100 & $\begin{array}{c}\text { Sangat } \\
\text { Baik }\end{array}$ \\
\hline 3 & $\begin{array}{l}\text { Diskusi } \\
\text { kelompok kelas }\end{array}$ & 100 & $\begin{array}{c}\text { Sangat } \\
\text { Baik }\end{array}$ \\
\hline 4 & $\begin{array}{l}\text { Mengajukan } \\
\text { pertanyaan }\end{array}$ & 100 & $\begin{array}{c}\text { Sangat } \\
\text { Baik }\end{array}$ \\
\hline
\end{tabular}

\begin{tabular}{|c|c|c|c|}
\hline & $\begin{array}{l}\text { kepada } \\
\text { teman/guru }\end{array}$ & & \\
\hline 5 & $\begin{array}{l}\text { Menjawab/mena } \\
\text { nggapi } \\
\text { pertanyaan } \\
\text { teman/guru }\end{array}$ & 100 & $\begin{array}{c}\text { Sangat } \\
\text { Baik }\end{array}$ \\
\hline 6 & $\begin{array}{l}\text { Memberikan } \\
\text { penjelasan }\end{array}$ & 100 & $\begin{array}{c}\text { Sangat } \\
\text { Baik }\end{array}$ \\
\hline 7 & $\begin{array}{l}\text { Meminta } \\
\text { bimbingan } \\
\text { kepada guru }\end{array}$ & 100 & $\begin{array}{c}\text { Sangat } \\
\text { Baik }\end{array}$ \\
\hline 8 & $\begin{array}{l}\text { Membuat } \\
\text { rangkuman/kesi } \\
\text { mpulan }\end{array}$ & 100 & $\begin{array}{c}\text { Sangat } \\
\text { Baik }\end{array}$ \\
\hline 9 & $\begin{array}{l}\text { Melakukan } \\
\text { kegiatan diluar } \\
\text { tugas belajar }\end{array}$ & 100 & $\begin{array}{c}\text { Sangat } \\
\text { Baik }\end{array}$ \\
\hline & ntase Aktivitas & 100 & $\begin{array}{c}\text { Sangat } \\
\text { Baik }\end{array}$ \\
\hline
\end{tabular}

\section{b) Hasil Analisis Respon Peserta Didik Terhadap Tembelajaran Kooperatif Tipe Jigsaw}

Tujuan utama analisis data respon peserta didik terhadap proses pembelajaran adalah untuk melihat bagaimana respon peserta didik terhadap proses pembelajaran kooperatif tipe Jigsaw. Hasil analisis tersebut ditunjukkan pada Tabel 4.8

Tabel 4.8 Hasil Respon peserta didik

\begin{tabular}{clcc}
\hline No & \multicolumn{1}{c}{ Aspek } & $\begin{array}{c}\text { Rata- } \\
\text { rata } \\
\text { Perse } \\
\text { ntase }\end{array}$ & $\begin{array}{c}\text { Keter } \\
\text { angan }\end{array}$ \\
\hline 1 & $\begin{array}{l}\text { Perangkat Pembelajaran } \\
\text { dan Proses Pembelajaran }\end{array}$ & 85,24 & SP \\
\hline 2 & Buku Peserta Didik & 93,70 & SP \\
\hline 3 & LKPD & 92,38 & SP \\
& Rata-rata total \% & 90,44 & SP \\
\hline
\end{tabular}

\section{c) Hasil Analisis Tes Hasil Belajar}

Tes yang digunakan pada penelitian ini ialah tes essay sebanyak lima nomor. Analisis tes digunakan untuk mengetahui tingkat pencapaian hasil belajar. Analisis selengkapnya dapat dilihat pada Lampiran. Rekapitulasi skor yang didapatkan peserta didik dapat dirangkum pada Tabel 4.9 
Tabel 4.9 Hasil Analisis Hasil Belajar Siswa Variabel

Nilai Statistik

\begin{tabular}{cc}
\hline Subjek penelitian & \\
Nilai ideal & 18 \\
Rata-rata & 100 \\
Nilai maksimum & 81,67 \\
Nilai minimum & 94,82 \\
Jumlah siswa yang & 75,86 \\
tuntas & 18 \\
Jumlah siswa yang tidak & - \\
tuntas & \\
\hline
\end{tabular}

Pada Tabel 4.9 terlihat bahwa hasil belajar siswa kelas X Keperawatan B SMK Negeri 3 Bantaeng terhadap pelajaran Kimia diperoleh skor rata-rata 81,67 dari skor ideal 100. Sedangkan secara individual, skor yang dicapai siswa, dari skor minimum 75,86 dan skor maksimum 94,82 dengan rentang skor 18,96 .

Pencapaian hasil belajar siswa pada materi konsep larutan dilihat dari aspek ketuntasan belajar setelah diterapkan pembelajaran kooperatif tipe Jigsaw pada Tabel 4.10

Tabel 4.10 Deskripsi Ketuntasan Pencapaian Hasil Belajar Siswa

\begin{tabular}{cccc}
\hline Skor & Kategori & Frekuensi & Persentase \\
\hline$<75$ & Tidak & - & - \\
$\geq 75$ & tuntas & 18 & 100 \\
& Tuntas & & \\
\hline
\end{tabular}

Berdasarkan hasil belajar dan ketuntasan belajar pada Tabel 4.10 terlihat bahwa ketuntasan pencapaian hasil belajar siswa adalah $100 \%$. Hal tersebut mengindikasikan bahwa perangkat pembelajaran kooperatif tipe Jigsaw yang dikembangkan telah layak digunakan berdasarkan dari pencapaian ketuntasan hasil belajar siswa yang tinggi. Pembelajaran dinyatakan efektif apabila $80 \%$ siswa yang mengikuti pembelajaran mampu mencapai nilai KKM yang telah ditetapkan, sehingga dapat disimpulkan berdasarkan hasil belajar dan ketuntasan belajar pada Tabel 4.10 bahwa pembelajaran kooperatif tipe Jigsaw dinyatakan efektif.

\section{Pembahasan Hasil Penelitian}

Pada bagian ini dikemukakan pembahasan hasil penelitian mencakup tiga hal, yaitu: (1) ketercapaian tujuan penelitian yang meliputi dua hal, yakni: proses pengembangan perangkat pembelajaran dan kualitas perangkat pembelajaran kooperatif tipe Jigsaw, (2) temuan-temuan khusus yang diperoleh selama proses pengembangan, dan (3) kendala-kendala yang dialami selama proses pengembangan. Pada dasarnya penelitian yang serupa telah pernah dilakukan oleh (Yusminiwati: 2012). Hasil yang diperoleh pada umumnya sama dengan hasil yang diperoleh pada penelitian pengembangan perangkat pembelajaran Kimia model kooperatif tipe Jigsaw pada materi konsep larutan yang dilakukan oleh penulis saat ini, yakni rata-rata hasil analisis kevalidan mencapai kriteris valid, hasil analisis kepraktisan berada pada kategori praktis dan hasil analisis keefektifan berada pada kategori efektif.

\section{a. Ketercapaian tujuan penelitian \\ 1. Proses pengembangan perangkat pembelajaran kooperatif tipe Jigsaw}

Proses pengembangan perangkat pembelajaran kooperatif tipe Jigsaw ini menggunakan model pengembangan 4-D. Dimana tahapan pertama dilakukan mulai dari tahap pendefinisian (define). Pada tahap ini dilakukan analisis awal akhir terhadap kegiatan belajar mengajar di sekolah. Selanjutnya dilakukan analisis siswa yang meliputi: latar belakang pengetahuan, perkembangan kognitif siswa, dan pengalaman belajar siswa dilanjutkan dengan analisis materi yang bertujuan untuk mengidentifikasi dan menyusun secara sistematis konsep-konsep utama yang berkaitan dengan materi konsep larutan. Hasil analisis materi digunakan untuk analisis tugas dan spesifikasi tujuan pembelajaran sehingga tujuan pembelajaran dapat tercapai.

Tahap kedua adalah tahap perancangan (design). Pada tahap ini dilakukan penyusunan tes dengan menggunakan acuan dan kisi-kisi tes hasil belajar, yang telah disusun berdasarkan 
spesifikasi tujuan pembelajaran. Penyusunan tes ini digunakan untuk mengetahui kemampuan dan pencapaian siswa terhadap tujuan pembelajaran. Selanjutnya, pemilihan media yang akan digunakan dalam proses pembelajaran serta pemilihan format. Format yang digunakan disesuaikan dengan format KTSP. Kegiatan utama dalam tahap perancangan adalah penyusunan perangkat pembelajaran kooperatif tipe Jigsaw pada materi konsep larutan untuk SMK Negeri 3 Bantaeng Kelas X Keperawatan B yang meliputi buku peserta didik, lembar kerja peserta didik, rencana pelaksanaan pembelajaran, dan tes hasil belajar. Semua hasil perangkat pembelajaran pada tahap ini disebut prototipe I.

Tahap ketiga adalah pengembangan (develop). Pada tahap ini dilakukan evaluasi perangkat pembelajaran koperatif tipe Jigsaw melalui serangkaian proses yakni: validasi ahli, revisi dan uji coba perangkat sehingga dihasilkan perangkat pembelajaran yang valid, praktis dan efektif. Tahap keempat adalah penyebaran (disseminate), dalam hal ini penyebaran dilakukan dengan penyebaran terbatas yakni pada MGMP Kimia SMK di Kab. Bantaeng.

Dari hasil analisis data respon guru diperoleh bahwa seluruh aspek yang dinyatakan dalam pelaksanaan kegiatan pembelajaran dengan menggunakan perangkat pembelajaran kooperatif tipe Jigsaw mendapatkan respon positif dari guru. Pada Lampiran terlihat bahwa 81,05\% (sangat positif) respon guru terhadap pembelajaran kooperatif tipe Jigsaw.

\section{Kualitas perangkat pembelajaran kooperatif tipe Jigsaw \\ a) Kevalidan}

Berdasarkan hasil penelitian dari dua validator, menunjukkan bahwa keseluruhan komponen perangkat pembelajaran dan instrumen (prototipe I) yang dinyatakan valid dengan revisi kecil. Oleh karena itu dilakukan revisi berdasarkan saran para ahli dan diperoleh prototipe II yang selanjutnya diujicobakan.
Hasil analisis validasi dari perangkat pembelajaran yaitu: untuk buku peserta didik diperoleh rata-rata sebesar 3,50 (berada pada kategori sangat valid), LKPD diperoleh rata-rata sebesar 3,45 (berada pada kategori valid), RPP diperoleh rata-rata sebesar 3,38 (berada pada kategor valid), dan Tes Hasil Belajar (THB) diperoleh ratarata 3,61 (berada pada kategori sangat valid). Berdasarkan rata-rata kesimpulan dari dua validator umumnya menyatakan bahwa perangkat pembelajaran yang dikembangkan dapat digunakan dengan revisi kecil. Demikian juga instrumen lainnya berada dalam batas interval $3,5 \leq \mathrm{M}$ $\leq 4$ (kategori sangat valid) yang artinya ratarata keseluruhan komponen yang divalidasi berada pada kategori sangat valid.

\section{b) Kepraktisan}

Secara umum hasil uji coba untuk kriteria kepraktisan telah memenuhi kriteria. Komponen kepraktisan untuk buku peserta didik dan LKPD ditentukan oleh dua hal: a) berdasarkan penilaian ahli (validator) dan praktisi, yang dinilai secara umum berdasarkan hasil pengetahuan dan pengalaman sebagai ahli dan praktisi, dan b) berdasarkan hasil pengamatan keterlaksanaan bahan ajar pada saat proses pembelajaran dilakukan di kelas.

Berdasarkan penilaian umum terhadap semua komponen yang divalidasi pada umumnya semua validator memberikan penilaian bahwa komponen yang dinilai dinyatakan dapat digunakan dengan sedikit revisi. Hasil pengamatan dua orang pengamat (observer) terhadap keterlaksanaan perangkat pembelajaran kooperatif tipe Jigsaw yang telah dilaksanakan pada uji coba, diperoleh hasil bahwa nilai keterlaksanaan perangkat dapat dikatakan memadai karena semua komponen-komponen yang menjadi penilaian dalam instrumen terlaksana seluruhnya dengan tingkat realibilitas yang tinggi, dengan menunjukkan rata-rata 3,81 yang berada pada rentang $3,5 \leq \mathrm{KI}<4,0$ yang berarti terlaksana seluruhnya, sehingga dapat disimpulkan bahwa perangkat 
pembelajaran kooperatif tipe Jigsaw memenuhi kriteria kepraktisan.

\section{c) Keefektifan}

Kriteria keefektifan perangkat pembelajaran meliputi: (1) ketercapaian hasil belajar, (2) kemampuan guru mengelola pembelajaran, (3) aktivitas siswa dan guru, serta (4) respon siswa. Hasil analisis data untuk keefektifan perangkat pembelajaran yang digunakan adalah sebagai berikut:

1) Ketercapaian hasil belajar

Untuk melihat ketercapaian kompetensi dasar dan indikator pembelajaran dengan menggunakan perangkat pembelajaran kooperatif tipe Jigsaw pada materi konsep larutan , maka dilakukan tes hasil belajar. Kriteria keefektifan terpenuhi jika siswa yang mencapai ketuntasan lebih besar atau sama dengan $(80 \%)$ artinya dari 18 siswa minimal 14 orang siswa harus mencapai batas KKM yang ditetapkan yaitu 75 . Berdasarkan uji coba yang telah dilakukan maka kriteria keefektifan perangkat pembelajaran tercapai dengan jumlah siswa yang mengalami ketuntasan sebesar $100 \%$ meskipun ada beberapa siswa yang memperoleh nilai yang agak rendah.

Berdasarkan dua respon siswa, salah satu hal yang membuat siswa lebih termotivasi untuk mengikuti proses pembelajaran adalah penggunaan buku peserta didik dan LKPD yang lebih menarik dari yang biasa mereka baca. Hasil penelitian validator terlihat bahwa pada indikator format buku peserta didik dan bahasa mendapat penilaian yang cukup tinggi yaitu sebesar 3,45 (kategori valid). Penggunaan ilustrasi yang menarik disertai dengan warna serta bahasa yang lebih mudah dimengerti merupakan salah satu faktor yang mendukung anggapan siswa mengenai buku peserta didik maupun LKPD yang menarik untuk dibaca. Kombinasi warna dan gambar (ilustrasi) lebih merangsang siswa secara visual karena otak memiliki kemampuan alami untuk pengenalan visual. Selanjutnya menurut Buzan(2005), hal inilah yang menyebabkan kita akan lebih mengingat informasi jika kita menggunakan gambar untuk menyajikannya. Dengan adanya rangsangan visual tersebut pada akhirnya dapat meningkatkan motivasi siswa dalam mengikuti proses pembelajaran. Hal ini terlihat dari jumlah siswa yang mengalami ketuntasan sebanyak 100\% meskipun masih ada beberapa orang siswa yang memperoleh nilai yang rendah atau sedikit diatas KKM.

Dari jumlah siswa sebanyak 18 orang, terdapat 5 orang yang memperoleh nilai yang rendah. Dari hasil analisis hasil belajar siswa yang terdapat pada Lampiran, terlihat bahwa sebagian besar siswa mengalami kesulitan dalam menjawab soal nomor 3 dan 5. Materi pada soal-soal tersebut merupakan materi tentang fraksi mol dan perhitungan $\mathrm{pH}$ asam dan basa. Kemungkinan besar siswa tersebut masih kurang paham mengenai cara perhitungan dan rumus yang akan digunakan dalam menentukan fraksi mol dan pH larutan asam dan basa.

Ketidakmampuan untuk membedakan rumus yang akan digunakan dalam menjawab soal adalah berhubungan erat dengan rendahnya kemampuan prasyarat siswa serta rendahnya kemampuan siswa untuk menghubungkan antara satu konsep yang telah dipelajari dengan konsep yang lain.

2) Aktivitas siswa

Kriteria keefektifan selanjutnya adalah keterlaksaan aktivitas siswa minimal terhadap $70 \%$ aspek yang diamati. Hal ini berarti dari sembilan aktivitas siswa yang diamati, enam diantaranya harus terlaksana. Berdasarkan hasil analisis data aktivitas siswa menunjukkan bahwa tujuh kategori pada aktivitas siswa terpenuhi yaitu: memperhatikan penjelasan guru, bekerja sama dalam kelompok, mengajukan pertanyaan pada teman/guru, menjawab/menanggapi pertanyaan teman/guru, memberi penjelasan pada teman yang membutuhkan, meminta bimbingan kepada guru jika mengalami kesulitan dalam kelompok, dan membuat rangkuman atau kesimpulan. 
Data aktivitas siswa yang mempunyai persentase terbesar adalah pada aktivitas kedua, yaitu aktif bekerja sama dalam kelompoknya menyelesaikan LKPD. Aktivitas ini terdiri dari aktivitas kelompok ahli dan aktivitas dalam kelompok asal. Dalam pembelajaran kooperatif tipe Jigsaw ini siswa berkesempatan untuk berkomunikasi dan berinteraksi sosial dengan temannya dalam kelompok ahli maupun kelompok asal sementara guru bertindak sebagai motivator dan fasilitator aktivitas siswa. Semua siswa mempunyai kesempatan untuk menjadi ahli dan bertanggung jawab untuk menjelaskan materi yang dipelajari dalam kelompok ahli kepada anggota kelompok yang lain dalam kelompok asal. Adanya tanggung jawab pribadi mengenai materi pelajaran dalam anggota kelompok sehingga siswa termotivasi untuk membantu temannya.

Menurut Slavin (2005), kunci model pembelajaran kooperatif tipe Jigsaw adalah interdependensi, yaitu tiap siswa bergantung kepada teman satu timnya untuk dapat memberikan informasi yang diperlukan supaya dapat berkinerja baik pada saat penilaian.

3) Respon siswa

Dari hasil analisis diperoleh bahwa seluruh aspek yang ditanyakan dalam pelaksanaan pembelajaran dengan menggunakan perangkat pembelajaran kooperatif tipe Jigsaw mendapat respon yang positif dari siswa. Berdasarkan hasil analisis respon siswa terhadap perangkat pembelajaran diperoleh bahwa 93,70\% siswa memberikan respon positif terhadap buku peserta didik, 92,38\% siswa memberikan respon positif terhadap LKPD dan $85,24 \%$ siswa memberikan respon positif terhadap perangkat pembelajaran dan proses pembelajaran. Dengan demikian dapat disimpulkan bahwa perangkat pembelajaran kooperatif tipe Jigsaw dapat mengarahkan siswa dalam belajar dan mencapai tujuan yang diinginkan.

Pada bagian akhir dari angket respon siswa, diberikan pertanyaan mengenai apakah ada kemajuan yang dirasakan oleh siswa setelah mengikuti kegiatan pembelajaran, sebagian besar diantaranya menjawab ada kemajuan yang dirasakan terutama dalam hal pemahaman mengenai materi pelajaran karena cara guru mengajar yang lebih menarik sehingga siswa merasa lebih mudah mengerti. Selain itu model pembelajaran yang digunakan membuat siswa merasa tertarik dan merasa senang sehingga membuat mereka lebih termotivasi dalam kegiatan pembelajaran tersebut.

\section{b. Temuan-temuan khusus yang diperoleh selama proses pengembangan}

Dalam proses pembelajaran utamanya dalam kegiatan kelompok asal maupun ahli, semua siswa mempunyai kesempatan untuk menjadi ahli. Sehingga kegiatan dalam kelompok bukan hanya didominasi oleh siswa-siswa yang pintar tetapi siswa-siswa yang agak lemah juga mampu berusaha untuk menjelaskan materi yang menjadi tugas keahliannya kepada anggota kelompok lainnya. Dengan demikian membantu siswasiswa yang agak lemah dalam peningkatan rasa percaya diri bahwa mereka juga mampu.

\section{c. Kendala-kendala yang dialami selama proses pengembangan}

Ada beberapa kendala yang dialami selama kegiatan pengembangan, terutama dalam kegiatan uji coba. Kendala-kendala yang dimaksudkan adalah:

1. Pada tahap uji coba pertemuan pertama, masih terkendala dalam hal pembagian kelompok untuk kelompok asal dan kelompok ahli tetapi pada pertemuan kedua dan ketiga tidak mengalami permasalahan lagi karena siswa sudah mengetahui cara pembagian kelompok asal maupun kelompok ahli dari pertemuan sebelumnya.

2. Pada saat pergantian posisi dari kelompok asal ke kelompok ahli dan sebaliknya kelompok ahli ke kelompok asal, alokasi waktunya melebihi waktu yang telah direncanakan sehingga alokasi waktu untuk kegiatan selanjutnya tidak maksimal lagi. 
3. Pada tahap uji coba, pada tahap presentasi tidak semua kelompok berkesempatan untuk mempresentasikan hasil diskusinya di depan kelas, hanya beberapa kelompok saja untuk mewakili materi yang sementara dibahas. Sehingga guru perlu memberikan penguatan yang lebih jelas lagi pada saat setelah presentasi siswa dilaksanakan.

4. Alokasi waktu yang telah ditentukan dalam RPP, masih sulit dicapai secara maksimal. Khususnya pada materi menghitung $\mathrm{pH}$ asam dan basa. Siswa memerlukan waktu yang cukup banyak dalam penyelesaian soal-soal.

\section{KESIMPULAN}

Berdasarkan hasil penelitian yang telah diuraikan, maka dapat disimpulkan sebagai berikut:

1. Proses pengembangan perangkat kooperatif tipe Jigsaw dimulai tahap pendefenisian yang meliputi analisis awal dan akhir mengenai gambaran awal proses pembelajaran dan gambaran fakta perangkat pembelajaran yang selama ini digunakan dalam proses belajar mengajar di SMK Negeri 3 Bantaeng. Setelah itu dilanjutkan dengan analisis mengenai alternatif pemecahan masalah yang diperlukan. Selanjutnya dari hasil analisis siswa dilanjutkan dengan analisis materi apa saja yang diperlukan dalam tahap proses pengembangan perangkat pembelajaran ini. Setelah itu dilanjutkan dengan analisis tugas yang mendukung pencapaian tujuan pembelajaran pada materti pokok Konsep Larutan kemudian dikonversikan menjadi tujuan pembelajaran. Tahap perancangan dimulai dengan penyusunan tes, pemilihan media, pemilihan format sampai diperoleh rancangan awal perangkat pembelajaran yang akan digunakan dalam penelitian. Tahap pengembangan dimulai dari analisis kevalidan, kepraktisan dan keefektifan perangkat pembelajaran yang digunakan kemudian dilanjutkan dengan tahap penyebaran perangkat yang telah diujicobakan dalam penelitian ini.

2. Kualitas perangkat pembelajaran kooperatif tipe Jigsaw yakni: a) sangat valid berdasarkan penilaian oleh validator ahli, b) perangkat yang telah dikembangkan memenuhi kriteria kepraktisan karena seluruh aspek pembelajaran dapat terlaksana, dan c) efektif karena aktifitas siswa berada pada batas interval toleransi dan hasil belajar berada pada ketuntasan klasikal.

DAFTAR PUSTAKA

Arikunto, Suharsimi. 1991. Dasar-dasar Evaluasi Pendidikan. Jakarta: Bumi Aksara

Depdiknas, 2003. Kurikulum 2004 Standar Kompetensi Mata Pelajaran Sains

Sekolah Menengah Atas, Jakarta: Depdiknas.

Hamalik, Oemar, 2002. Perencanaan Pengajaran Berdasarkan Pendekatan Sistem. Jakarta: Bumi Akasara

Huda, Miftahul, 2011. Cooperative Learning. Yogyakarta: Pustaka Pelajar.

Hobri, 2009. Metodologi Penelitian Pengembangan (development research).(online.http://hobri.blog.u nej.ac.id.files/2009/03/05). Diakses 6 November 2011.

Ibrahim, dkk. 2000. Pembelajaran Kooperatif. Surabaya: University Press.

Isjoni, 2011. Pembelajaran Kooperatif: Meningkatkan Kecerdasan Komunikasi Antar Peserta Didik. Yogjakarta: Pustaka Pelajar.

Irawati, Ardi. 2014. Langkah-langkah Pembelajaran Kooperatif. (Online), http//irawatiardi.blogspot.com/2014 $/ 12$.

Jensen, Eric. 2008. Brain Based Learning: pembelajaran Berbasis

Kemampuan Otak. Yogyakarta: Pustaka Pelajar. 

Jumriati, $2008 . \quad$ Pengembangan
Perangkat Pembelajaran
Matematika Berbasis Contextual
Teaching dan Learning. Tesis
FMIPA UNM Makassar. Tidak
Diterbitkan.

Nurdin, 2007. Model Pembelajaran Matematika yang Menumbuhkan

Metakognitif

untuk Menguasai Bahan Ajar.

Disertasi. Tidak diterbitkan.

Surabaya: PPs Unesa

Nur, Mohamad. 2011. Model Pembelajaran

Kooperatif. Edisi 2. Jakarta: Unesa

Riduan. 2004. Metode Riset. Jakarta: Rineka

Cipta

Riduan. 2010. Metode dan Teknik

Penyusunan Tesis. Bandung:

Alfabeta

Rusman, 2012. Model-model Pembelajaran, Edisi 2. Jakarta: Grafindo

Sanjaya, Wina. 2006. Strategi

Pembelajaran. Jakarta: Kencana

Sardiman, 2012. Interaksi \& Motivasi

Belajar Mengajar. Jakarta:

RajaGrafindo

Slavin, Robert E. 2005. Cooperative Learning: Teori, Riset dan Praktik. Terjemahan

Oleh Yusron, Narulita. 2008. Bandung: Penerbit Nusa Media.

Trianto, 2009. Mendesain Model

Pembelajaran Inovatif-Progresif.

Jakarta: Kencana

Trianto. 2010. Model Pembelajaran

Terpadu. Jakarta: Bumi Akasara

Yusminiwati. 2012. Pengembangan

Perangkat Pembelajaran Kooperatif

Tipe Jigsaw

Berbantuan Mind Map (Studi Pada Materi

Pokok Larutan Penyangga). Tesis.

Makassar: PPs UNM. 